\title{
STUDI SUHU DAN KELEMBABAN RUMAH PENDERITA ISPA PADA BALITA DI DESA GANDATAPA KECAMATAN SUMBANG KABUPATEN BANYUMAS TAHUN 2018
}

\author{
Nilam Safitri Ariani 1), M. Choiroel Anwar ${ }^{2)}$ \\ Jurusan Kesehatan Lingkungan, Politeknik Kesehatan Kemenkes Semarang, \\ Jl. Raya Baturraden KM 12 Purwokerto, Indonesia
}

\begin{abstract}
Abstrak
[Studi suhu dan kelembaban rumah penderita ISPA pada balita di Desa Gandatapa Kecamatan Sumbang Kabupaten Banyumas Tahun 2018] Faktor risiko terjadinya penyakit ISPA salah satunya suhu dan kelembaban yang tidak memenuhi syarat kesehatan. Desa Gandatapa merupakan wilayah dengan angka penyakit ISPA cukup tinggi mencapai 49 penderita. Tujuan dari penelitian ini untuk mengetahui kualitas suhu dan kelembaban di rumah penderita ISPA di Desa Gandatapa Kecamatan Sumbang Kabupaten Banyumas. Metode yang digunakan dalam penelitian ini adalah metode deskriptif dengan mengambil subyek sampel penelitian sebanyak 49 rumah atau total dari penderita ISPA dengan melakukan pengukuran di ruang tidur dan ruang keluarga. Hasil penelitan menunjukkan bahwa penderita ISPA di Desa Gandatapa, suhu pada ruang tidur yang memenuhi syarat $(73,47 \%)$ dan suhu pada ruang keluarga yang memenuhi syarat $(83,67 \%)$, kelembaban pada ruang tidur yang memenuhi syarat $(65,31 \%)$ dan kelembaban pada ruang keluarga yang memenuhi syarat $(61,22 \%)$. Kesimpulan dari hasil pemeriksaan, diketahui suhu rumah penderita ISPA yang memenuhi syarat pada ruang tidur 36 rumah dan pada ruang keluarga 41 rumah, kelembaban rumah penderita ISPA pada ruang tidur yang memenuhi syarat 17 rumah dan pada ruang keluarga yang memenuhi syarat 19 rumah.
\end{abstract}

Kata kunci: Rumah penderita ISPA, suhu, kelembaban

\begin{abstract}
[Study of temperature and humidity of ispa patient's home on the toddler in gandatapa village, sumbang sub district, banyumas regency of 2018] One of factors risk the occurrence of URIs disease are temperature and humidity that do not eligible for health requirements. Gandatapa village is a region with a high rate of URIs disease reached 49 patients. The purpose of this study to determine the quality of temperature and humidity in the home of patients with ARI in Gandatapa village, Sumbang sub district, Banyumas regency. The method used in this research is descriptive method by taking 49 houses or the total of patients with URIs by measuring in the sleeping room and family room. The result of the research showed that the patient of URIs in Gandatapa Village was known that the temperature in the sleeping room was eligible $(73,47 \%)$ and the temperature in the eligible family room $(83,67 \%)$, humidity in the eligible sleeping room $(65,31 \%)$ and humidity in eligible family room $(61,22 \%)$. The conclusion from the results, home temperature URIs patient in the eligible sleeping room thirty six houses and the temperature in the eligible family room fourty one houses, humidity in the eligible sleeping room seventeen houses and humidity in eligible family room nineteen house.
\end{abstract}

Keywords: ISPA patient's home, temperature, humidity

1)Email : nilamsafitri905@gmail.com

${ }^{2)}$ Email : choirul1960@gmail.com 


\section{Pendahuluan}

Penyakit ISPA merupakan penyakit yang paling sering menyebabkan kematian pada anak balita, sehingga ISPA masih merupakan penyakit yang mengakibatkan kematian cukup tinggi (WHO, 2007). Menurut Depkes RI (2005), Infeksi Saluran Pernapasan Akut (ISPA) adalah penyakit Infeksi akut yang menyerang salah satu bagian dan atau lebih dari saluran napas mulai dari hidung (saluran atas) hingga alveoli (saluran bawah) termasuk jaringan adneksanya seperti sinus, rongga telinga tengah dan pleura.

Suhu dan kelembaban merupakan faktor yang berpengaruh terhadap kejadian ISPA. Suhu dan kelembaban sangat erat kaitannya dengan pertumbuhan dan perkembangan faktor etiologi pneumonia yang berupa virus, bakteri, dan jamur. Faktor etiologi ini dapat tumbuh dengan baik jika kondisi yang optimum. Virus, bakteri, dan jamur penyebab ISPA untuk pertumbuhan dan perkembangbiakannya membutuhkan suhu dan kelembaban yang optimal. Pada suhu dan kelembaban tertentu memungkinkan pertumbuhannya terhambat bahkan tidak tumbuh sama sekali atau mati. Tapi pada suhu dan kelembaban tertentu dapat tumbuh dan berkembang dengan sangat cepat. Hal inilah yang membahayakan karena sering anak berada dalam ruangan dengan kondisi tersebut dan dalam jangka waktu yang lama maka anak terpapar faktor risiko tersebut. Akibatnya makin besar peluang anak untuk terjangkit penyakit ISPA (Heru Padmonobo, $d k k, 2010$, h.197). Suhu dimana bakteri dapat tumbuh dalam rentang suhu $25^{\circ} \mathrm{C}-40^{\circ} \mathrm{C}$, akan tetapi bisa tumbuh secara optimal pada suhu $31^{\circ} \mathrm{C}-37^{\circ} \mathrm{C}$, sedangkan untuk kelembaban dapat membuat bakeri tumbuh secara optimal pada suhu diatas $60 \%$ (Eka Luvita Sari, dkk, 2014, hal. 60-61).

Menurut data Dinas Kesehatan Banyumas Tahun 2016 penyakit ISPA menduduki peringkat tertinggi kedua yaitu di Wilayah Kerja Puskesmas II Sumbang. Puskesmas II Sumbang memiliki 8 wilayah kerja meliputi Desa Gandatapa, Sikapat, Ciberem, Susukan, Banjar Sari Wetan, Banjar Sari Kulon, Kotayasa, dan Limpakuwus. Dari 8 desa tersebut yang mempunyai masalah penyakit ISPA pada balita tertinggi yaitu di Desa Gandatapa dengan jumlah penderita yang ditemukan 49 balita (Profil Kesehatan Puskesmas II Sumbang Tahun 2017).

Berdasarkan hal tersebut peneliti tertarik untuk mengadakan penelitian tentang masalah tersebut dengan judul "Studi Suhu dan Kelembaban Rumah Penderita ISPA Pada Balita Di Desa Gandatapa Kecamatan Sumbang Kabupaten Banyumas Tahun 2018".

Rumusan masalah dari penelitian ini yaitu bagaimana kualitas suhu dan kelembaban di rumah penderita ISPA pada balita di Desa Gandatapa Kecamatan Sumbang Kabupaten Banyumas.

Tujuan penelitian ini untuk mengetahui kualitas suhu dan kelembaban di rumah penderita ISPA pada balita.

\section{Bahan dan Metode}

Penelitian ini bersifat deskriptif observasional dengan cara melakukan pengukuran suhu dan kelembaban di rumah penderita ISPA yang bertujuan untuk mengetahui hasil suhu dan kelembaban di rumah penderita ISPA dan kemudian dibandingkan dengan Permenkes RI Nomor 1077/MENKES/V/2011 tentang Pedoman Penyehatan Udara Dalam Ruang Rumah. Pengumpulan data dilakukan dengan cara observasi dan pengukuran. Instrumen yang digunakan berupa termohygrometer, lux meter, rolmeter, dan ceklist.

\section{Hasil dan Pembahasan}

a. Data Umum

Keadaan Geografi

Desa gandatapa merupakan salah satu wilayah kecamatan Sumbang dengan luas wilayah 544 Ha. Kecamatan Sumbang terbagi dalam 8 desa bagian atau kelurahan antara lain Desa Gandatapa, Sikapat, Ciberem, Susukan, Banjarsari Wetan, Banjarsari Kulon, Kotayasa, dan Limpakuwus.

Suhu yang tercatat dari hasil pengumpulan rata-rata adalah $29^{\circ} \mathrm{C}$, dengan demikian suhu di Desa Gandatapa memenuhi persyaratan kesehatan dengan range antara $18-30^{\circ} \mathrm{C}$. Dalam kondisi suhu tersebut maka nyaman digunakan dalam beristirahat.

Keadaan Demografi

Pertumbuhan Penduduk

Berdasarkan data dari Balai Desa Gandatapa tahun 2018 jumlah penduduk Desa Gandatapa berjumlah 9620 jiwa terdiri dari 4938 jiwa laki-laki $(51,3 \%)$ dan 4682 jiwa perempuan $(48,7 \%)$, tidak terjadi perbedaan yang signifikan hanya selisih 256 jiwa $(2,7 \%)$ dan tergabung dalam 3101 rumah tangga atau KK.

Jumlah penduduk menurut golongan umur

Jumlah penduduk di Desa Gandatapa menurut golongan umur diketahui bahwa penduduk dengan umur 10-19 tahun merupakan kelompok umur terbanyak dengan jumlah jiwa 1609 (16,72\%), sedangkan untuk penduduk umur 60-69 merupakan kelompok umur yang terendah dengan jumlah jiwa 582 (6,04\%).

Data jumlah penduduk menurut golongan umur di Desa Gandatapa tahun 2018 sebagai berikut : 
Tabel 1. Distribusi jumlah penduduk menurut golongan umur

\begin{tabular}{cccc}
\hline NO & $\begin{array}{c}\text { GOL. } \\
\text { UMUR }\end{array}$ & JML & $\%$ \\
\hline 1 & $0-9$ & 1431 & 14,87 \\
2 & $10-19$ & 1609 & 16,72 \\
3 & $20-29$ & 1458 & 15,15 \\
4 & $30-39$ & 1479 & 15,37 \\
5 & $40-49$ & 1365 & 14,18 \\
6 & $50-59$ & 915 & 9,51 \\
7 & $60-69$ & 582 & 6,04 \\
8 & $<69$ & 781 & 8,11 \\
& JUMLAH & 9620 & 100 \\
\hline
\end{tabular}

Jumlah penduduk menurut golongan pendidikan

Tabel 2. Distribusi jumlah penduduk menurut golongan pendidikan

\begin{tabular}{|c|c|c|c|}
\hline NO & $\begin{array}{l}\text { GOLONGAN } \\
\text { PENDIDIKAN }\end{array}$ & JML & $\%$ \\
\hline 1 & $\begin{array}{l}\text { TIDAK/BELUM } \\
\text { SEKOLAH }\end{array}$ & 2151 & 22,36 \\
\hline 2 & $\begin{array}{c}\text { BELUM TAMAT } \\
\text { SD/ } \\
\text { SEDERAJAT }\end{array}$ & 2657 & 27,62 \\
\hline 3 & $\begin{array}{l}\text { TAMAT SD/ } \\
\text { SEDERAJAT }\end{array}$ & 3184 & 33,10 \\
\hline 4 & $\begin{array}{c}\text { SLTP/ } \\
\text { SEDERAJAT }\end{array}$ & 1063 & 11,05 \\
\hline 5 & $\begin{array}{c}\text { SLTA/ } \\
\text { SEDERAJAT }\end{array}$ & 431 & 4,48 \\
\hline 6 & $\begin{array}{l}\text { DIPLOMA I/II } \\
\text { AKADEMI/ }\end{array}$ & 14 & 0,14 \\
\hline 7 & $\begin{array}{c}\text { DIPLOMA } \\
\text { III/S.MUDA }\end{array}$ & 34 & 0,35 \\
\hline 8 & $\begin{array}{l}\text { DIPLOMA } \\
\text { IV/STRATA I }\end{array}$ & 81 & 0,84 \\
\hline 9 & STRATA II & 4 & 0,04 \\
\hline 10 & $\begin{array}{l}\text { STRATA III } \\
\text { JUMLAH }\end{array}$ & $\begin{array}{c}1 \\
9620 \\
\end{array}$ & $\begin{array}{c}0,01 \\
100 \\
\end{array}$ \\
\hline
\end{tabular}

Kondisi penduduk dengan golongan pendidikan tamat SD/sederajat $(33,10 \%)$ lebih banyak dibandingkan dengan penduduk yang memiliki golongan pendidikan tamat SLTP/sederajat $(11,05 \%)$.

Jumlah penduduk menurut mata pencaharian

Tabel 3. Distribusi jumlah penduduk menurut golongan mata pencaharian

\begin{tabular}{|c|c|c|c|}
\hline NO & PEKERJAAN & $\begin{array}{c}\text { JUMLAH } \\
\text { (JIWA) }\end{array}$ & $\%$ \\
\hline 1 & $\begin{array}{c}\text { Karyawan } \\
\text { swasta }\end{array}$ & 540 & 5,61 \\
\hline 2 & Wiraswasta & 430 & 4,47 \\
\hline 3 & $\begin{array}{c}\text { Buruh harian } \\
\text { lepas }\end{array}$ & 5875 & 61,07 \\
\hline 4 & Petani & 781 & 8,12 \\
\hline 5 & Pedagang & 850 & 8,84 \\
\hline \multirow[t]{2}{*}{6} & Buruh tani & 1144 & 11,89 \\
\hline & JUMLAH & 9620 & 100 \\
\hline
\end{tabular}

Mata pencaharian penduduk Desa Gandatapa yaitu buuruh harian lepas dengan jumlah penduduk $5875(61,07 \%)$ dibandingkan dengan mata pencaharian yang lain.

Karakteristik penderita ISPA

Kondisi balita dan keluarga balita

Umur balita penderita ISPA

Tabel 4. Distribusi frekuensi umur balita penderita ISPA

\begin{tabular}{cccc}
\hline NO & UMUR & JML & $\%$ \\
& BALITA & $($ JIWA $)$ & \\
\hline 1 & $0-11$ Bulan & 6 & 12,24 \\
2 & $1-5$ Tahun & 43 & 87,76 \\
& JUMLAH & 49 & 100 \\
\hline
\end{tabular}

Umur balita di Desa Gandatapa yang terbesar yaitu umur 1-5 tahun dengan jumlah 43 balita $(87,76 \%)$ dibandingkan dengan umur 0-11 bulan hanya berjumlah 6 balita $(12,24 \%)$.

Jenis kelamin balita

Tabel 5. Distribusi frekuensi jenis kelamin balita penderita ISPA

\begin{tabular}{cccc}
\hline NO & JENIS & JML & $\%$ \\
& KELAMIN & (JIWA) & \\
\hline 1 & Laki-laki & 25 & 51,02 \\
2 & Perempuan & 24 & 48,98 \\
& JUMLAH & 49 & 100 \\
\hline
\end{tabular}

Jenis kelamin balita di Desa Gandatapa yaitu jenis kelamin laki-laki lebih banyak dengan jumlah 25 balita $(51,02 \%)$, sedangkan untuk jenis kelamin perempuan 24 balita $(48,98 \%)$. Namun, perbedaan jumlahnya tidak jauh dan hampir dikatakan sebanding antara jenis laki-laki dan perempuan.

Pendidikan kepala keluarga

Tabel 6. Distribusi frekuensi pendidikan kepala keluarga balita penderita ISPA

\begin{tabular}{cccc}
\hline NO & PENDIDIKAN & $\begin{array}{c}\text { JML } \\
(\text { JIWA })\end{array}$ & $\%$ \\
\hline 1 & & 43 & 87,75 \\
2 & SD & 3 & 6,12 \\
3 & SLTP & 3 & 6,12 \\
& SLTA & 49 & 100 \\
\hline
\end{tabular}

Kepala keluarga balita di Desa Gandatapa mayoritas berpendidikan SD dengan jumlah 43 jiwa $(87,75 \%)$.

Pekerjaan kepala keluarga

Pekerjaan kepala keluarga di Desa Gandatapa sebagai petani, pedagang, kuli bangunan, pekerja proyek, buruh harian lepas, karyawan swasta, dan wiraswasta. Sebagian besar kepala keluarga balita memiliki pekerjaan sebagai buruh harian lepas dengan jumlah 34 jiwa $(69,39 \%)$ dibandingkan dengan pekerjaan yang lain. 
Tabel 7. Distribusi frekuensi pekerjaan kepala keluarga balita penderita ISPA

\begin{tabular}{|c|c|c|c|}
\hline $\mathrm{NO}$ & PEKERJAAN & $\begin{array}{c}\text { JML } \\
\text { (JIWA) }\end{array}$ & $\%$ \\
\hline 1 & $\begin{array}{l}\text { Karyawan } \\
\text { swasta }\end{array}$ & 5 & 10,20 \\
\hline 2 & Wiraswasta & 2 & 4,08 \\
\hline 3 & $\begin{array}{l}\text { Buruh harian } \\
\text { lepas }\end{array}$ & 34 & 69,39 \\
\hline 4 & Petani & 1 & 2,04 \\
\hline 5 & Pedagang & 2 & 4,08 \\
\hline 6 & Kuli bangunan & 1 & 2,04 \\
\hline 7 & Pekerja proyek & 1 & 2,04 \\
\hline \multirow[t]{2}{*}{8} & Buruh tani & 3 & 6,12 \\
\hline & JUMLAH & 49 & 100 \\
\hline
\end{tabular}

b. Data Khusus

Suhu

Tabel 8. Distribusi suhu rumah penderita ISPA

\begin{tabular}{|c|c|c|c|c|}
\hline $\mathrm{NO}$ & RUANGAN & SUHU & JML & $\%$ \\
\hline \multirow{5}{*}{1} & & Memenuhi & & \\
\hline & Kamar tidur & $\begin{array}{c}\text { Syarat } 18- \\
30^{\circ} \mathrm{C}\end{array}$ & 36 & 73,47 \\
\hline & & Tidak & & \\
\hline & & $\begin{array}{l}\text { Memenuhi } \\
\text { syarat }\end{array}$ & 13 & 26,53 \\
\hline & JUMLAH & & 49 & 100 \\
\hline \multirow[t]{5}{*}{2} & $\begin{array}{c}\text { Ruang } \\
\text { keluaroa }\end{array}$ & $\begin{array}{l}\text { Memenuhi } \\
\text { Syarat 18- }\end{array}$ & 41 & 83,67 \\
\hline & & $30^{\circ} \mathrm{C}$ & & \\
\hline & & Memenuhi & 8 & 16,33 \\
\hline & & syarat & & \\
\hline & JUMLAH & & & 100 \\
\hline
\end{tabular}

Suhu ruang tidur yang memenuhi syarat sebanyak 36 rumah $(73,47 \%)$ dan 13 rumah $(26,53 \%)$ tidak memenuhi syarat, sedangkan untuk ruang keluarga di dapatkan hasil yang memenuhi syarat sebanyak 41 rumah $(83,67 \%)$ dan yang tidak memenuhi syarat sebanyak 8 rumah $(16,33 \%)$.

$\begin{array}{cccc}\text { Suhu } & \text { menurut } & \text { Peraturan } & \text { Menteri } \\ \text { Kesehatan } & \text { Republik } & \text { Indonesia } & \text { No. }\end{array}$ 1077/MENKES/PER/V/2011 yang memenuhi syarat berkisar antara $18^{\circ} \mathrm{C}$ sampai $30^{\circ} \mathrm{C}$. Data yang diperoleh suhu rumah penderita ISPA pada balita di Desa Gandatapa yang memenuhi syarat kesehatan lebih banyak dibandingkan dengan jumlah rumah yang tidak memenuhi syarat, oleh karena itu disarankan untuk selalu memperhatikan suhu di dalam rumah agar selalu segar dan nyaman untuk dijadikan tempat istirahat. Pada saat penderita nyaman dan optimal dalam beristirahat akan membentuk daya tahan tubuh yang baik dan mempercepat proses penyembuhan penyakit ISPA.

Kelembaban
Tabel 9. Distribusi kelembaban rumah penderita ISPA

\begin{tabular}{|c|c|c|c|c|}
\hline NO & $\begin{array}{c}\text { RUANG } \\
\text { AN }\end{array}$ & KELEMBABAN & JML & $\%$ \\
\hline \multirow[t]{4}{*}{1} & $\begin{array}{c}\text { Kamar } \\
\text { tidur }\end{array}$ & $\begin{array}{l}\text { Memenuhi } \\
\text { Syarat } 18 \text { - } \\
30^{\circ} \mathrm{C}\end{array}$ & 36 & 73,47 \\
\hline & & Tidak & & \\
\hline & & $\begin{array}{l}\text { Memenuhi } \\
\text { syarat }\end{array}$ & 13 & 26,53 \\
\hline & JUMLAH & & 49 & 100 \\
\hline \multirow[t]{4}{*}{2} & $\begin{array}{l}\text { Ruang } \\
\text { keluarga }\end{array}$ & $\begin{array}{c}\text { Memenuhi } \\
\text { Syarat } 18 \text { - } \\
30^{\circ} \mathrm{C}\end{array}$ & 41 & 83,67 \\
\hline & & Tidak & & \\
\hline & & $\begin{array}{c}\text { Memenuhi } \\
\text { syarat }\end{array}$ & 8 & 16,33 \\
\hline & JUMLAH & & 49 & 100 \\
\hline
\end{tabular}

Kelembaban untuk ruang kamar tidur 17 rumah memiliki nilai kelembaban $(34,69 \%), 32$ rumah memiliki nilai kelembaban $(65,31 \%)$. Sedangkan untuk ruang keluarga 19 rumah memiliki nilai kelembaban $(38,78 \%), 30$ rumah memiliki nilai kelembaban $(61,22 \%)$.

Kelembaban dalam ruangan rumah menurut Peraturan Menteri Kesehatan Republik Indonesia No. 1077/MENKES/PER/V/2011 adalah 40-60 \%. Sehingga data yang diperoleh dari hasil pengukuran kelembaban di rumah penderita ISPA lebih banyak yang tidak memenuhi syarat kesehatan, hal tersebut disebabkan tidak terdapatnya ventilasi dan terdapat ventilasi yang $\leq 10 \%$ dari luas lantai baik di ruang kamar tidur maupun di ruang keluarga. Kelembaban yang tinggi juga disebabkan kecilnya intensitas cahaya yang masuk kedalam rumah penderita ISPA.

Upaya yang dapat dilakukan untuk rumah yang tidak memenuhi syarat kelembaban yaitu dengan menjaga temperatur dan kelembaban udara dalam ruangan dengan cara membuat ventilasi dalam rumah, memasang genting kaca untuk membantu cahaya masuk ke dalam rumah, dan penghuni rumah rutin membuka jendela atau gorden setiap hari.

Luas ventilasi

Luas ventilasi rumah penderita ISPA pada balita di Desa Gandatapa untuk ruang kamar tidur yang memenuhi syarat sebanyak 9 rumah $(18,37 \%)$ dan yang tidak memenuhi syarat sebanyak 40 rumah $(81,63 \%)$, sedangkan untuk ruang keluarga hasil pengukuran luas ventilasi yang memenuhi syarat sebanyak 16 rumah $(32,65 \%)$ dan yang tidak memenuhi syarat sebanyak 33 rumah $(67,35 \%)$.

Luas ventilasi ruangan yang memenuhi syarat menurut Peraturan Menteri Kesehatan 
Republik

Indonesia

No. 1077/MENKES/PER/V/2011 adalah minimal $10 \%$ dari luas lantai sehingga udara yang masuk tidak terlalu besar dan tidak terlalu kecil atau sedikit. Data yang diperoleh dari hasil pengukuran luas ventilasi di rumah penderita ISPA lebih banyak yang tidak memenuhi syarat kesehatan.

Tabel 10. Distribusi luas ventilasi rumah penderita ISPA

\begin{tabular}{|c|c|c|c|c|}
\hline $\mathrm{NO}$ & $\begin{array}{c}\text { RUANG } \\
\text { AN }\end{array}$ & $\begin{array}{c}\text { LUAS } \\
\text { VENTILASI }\end{array}$ & JML & $\%$ \\
\hline \multirow{5}{*}{1} & & Memenuhi & & \\
\hline & Kamar tidur & $\begin{array}{l}\text { Syarat } \geq 10 \% \text { dari } \\
\text { luas lantai }\end{array}$ & 9 & 18,37 \\
\hline & & Tidak & & \\
\hline & & $\begin{array}{l}\text { Memenuhi } \\
\text { syarat }\end{array}$ & 40 & 81,63 \\
\hline & JUMLAH & & 49 & 100 \\
\hline \multirow[t]{4}{*}{2} & $\begin{array}{l}\text { Ruang } \\
\text { keluarga }\end{array}$ & $\begin{array}{c}\text { Memenuhi } \\
\text { Syarat } \geq 10 \% \text { dari } \\
\text { luas lantai }\end{array}$ & 16 & 32,65 \\
\hline & & Tidak & & \\
\hline & & $\begin{array}{l}\text { Memenuhi } \\
\text { syarat }\end{array}$ & 33 & 67,35 \\
\hline & JUMLAH & & 49 & 100 \\
\hline
\end{tabular}

Upaya yang dapat dilakukan pada rumah yang luas ventilasinya tidak memenuhi syarat yaitu membuat lubang ventilasi minimal $10 \%$ dari luas lantai sehingga udara yang masuk dapat optimal, tinggi lubang ventilasi maksimal $80 \mathrm{~cm}$ dari langit-langit, dan tinggi jendela dapat dibuka dan ditutup minimal $80 \mathrm{~cm}$.

Pencahayaan alami

Tabel 11. Distribusi pencahayaan alami rumah penderita ISPA

\begin{tabular}{|c|c|c|c|c|}
\hline NO & $\begin{array}{c}\text { RUANG } \\
\text { AN }\end{array}$ & PENCAHAYAAN & JML & $\%$ \\
\hline \multirow[t]{3}{*}{1} & $\begin{array}{l}\text { Kamar } \\
\text { tidur }\end{array}$ & $\begin{array}{c}\text { Memenuhi } \\
\text { Syarat } \geq 60 \text { lux }\end{array}$ & 7 & 14,29 \\
\hline & & $\begin{array}{c}\text { Tidak } \\
\text { Memenuhi } \\
\text { syarat } \\
\end{array}$ & 42 & 85,71 \\
\hline & JUMLAH & & 49 & 100 \\
\hline \multirow[t]{3}{*}{2} & $\begin{array}{l}\text { Ruang } \\
\text { keluarga }\end{array}$ & $\begin{array}{c}\text { Memenuhi } \\
\text { Syarat } \geq 60 \text { lux }\end{array}$ & 19 & 38,78 \\
\hline & & $\begin{array}{c}\text { Tidak } \\
\text { Memenuhi } \\
\text { syarat }\end{array}$ & 30 & 61,22 \\
\hline & JUMLAH & & 49 & 100 \\
\hline
\end{tabular}

Pencahayaan alami pada ruang kamar tidur yang memenuhi syarat 7 rumah $(14,29 \%)$ dan yang tidak memenuhi syarat 42 rumah $(85,71 \%)$, sedangkan untuk ruang keluarga yang memenuhi syarat 19 rumah $(38,78 \%)$ dan 30 rumah $(61,22 \%)$ tidak memenuhi syarat.

Pencahayaan memenuhi syarat menurut Peraturan Menteri Kesehatan Republik Indonesia No. 1077/MENKES/PER/V/2011 adalah minimal 60 Lux. Dalam kondisi pencahayaan tersebut maka dapat diketahui bahwa sinar matahari dapat masuk ke dalam ruangan secara optimal. Data dari hasil pengkuran pencahayaan pada rumah penderita ISPA banyak yang pencahayaannya tidak memenuhi syarat kesehatan.

Upaya yang dapat dilakukan pada rumah yang memiliki pencahayaan tidak memenuhi syarat yaitu mengubah perilaku penghuni yang malas membuka jendela atau gorden, memasang genting kaca agar sinar matahari dapat masuk secara optimal ke dalam rumah dan mengurangi tingkat kelembaban, serta memeperhatikan luas ventilasi minimal $10 \%$ dari luas lantai.

Kondisi lantai

Tabel 12. Distribusi kondisi lantai rumah penderita ISPA

\begin{tabular}{|c|c|c|c|c|}
\hline $\mathrm{NO}$ & $\begin{array}{c}\text { RUANG } \\
\text { AN }\end{array}$ & $\begin{array}{l}\text { KONDISI } \\
\text { LANTAI }\end{array}$ & JML & $\%$ \\
\hline \multirow[t]{3}{*}{1} & Kamar tidur & Kedap air & 4 & 8,16 \\
\hline & & Tidak kedap air & 45 & 91,84 \\
\hline & JUMLAH & & 49 & 100 \\
\hline \multirow[t]{3}{*}{2} & $\begin{array}{l}\text { Ruang } \\
\text { keluarga }\end{array}$ & Kedap air & 4 & 8,16 \\
\hline & & Tidak kedap air & 45 & 91,84 \\
\hline & JUMLAH & & 49 & 100 \\
\hline
\end{tabular}

Kondisi lantai pada rumah penderita ISPA di Desa Gandatapa untuk ruangan kamar tidur yang lantainya kedap air sebanyak 4 rumah $(8,16 \%)$ dan yang tidak kedap air sebanyak 45 rumah $(91,84 \%)$, sedangkan untuk kondisi lantai pada ruang keluarga yang memenuhi syarat dengan kondisi lantai kedap air sebanyak 4 rumah $(8,16 \%)$ dan yang tidak kedap air sebanyak 45 rumah $(91,84 \%)$

Kondisi lantai menurut Keputusan Menteri Kesehatan Republik Indonesia No.829/MENKES/SK/VII/1999 adalah kondisi lantai yang kedap air dan mudah dibersihkan. Data hasil pengamatan kondisi lantai rumah penderita ISPA masih banyak yang memiliki lantai tidak kedap air atau masih tanah sehingga membuat tingkat kelembaban tinggi.

Upaya yang dapat dilakukan pada rumah yang kondisi lantainya belum kedap air yaitu lantai harus dilapisi bahan yang kedap sehingga mencegah masuknya air kedalam rumah. Lantai yang tidak memenuhi syarat kesehatan dapat 
menjadikan udara dalam ruangan menjadi lembab, menjadi tempat berkembangbiakan vektor, dan pada musim panas lantai menjadi kering sehingga menimbulkan debu yang berbahaya bagi penghuni rumah.

\section{Penutup}

Suhu rumah penderita ISPA pada balita di Desa Gandatapa untuk ruang kamar tidur yang memenuhi syarat sebanyak 36 rumah $(73,47 \%)$, sedangkan untuk ruang keluarga yang memenuhi syarat sebanyak 41 rumah $(83,67 \%)$.

Kelembaban rumah penderita ISPA pada balita di Desa Gandatapa untuk ruang kamar tidur yang memenuhi syarat berjumlah 17 rumah $(34,69 \%)$, sedangkan untuk ruang keluarga yang memenuhi syarat berjumlah 19 rumah $(38,78 \%)$.

Luas Ventilasi rumah penderita ISPA pada balita di Desa Gandatapa untuk ruang kamar tidur yang memiliki luas ventilasi memenuhi syarat sebanyak 9 rumah (18,37\%), sedangkan untuk ruang keluarga yang luas ventilasinya memenuhi syarat sebanyak 16 rumah $(32,65 \%)$.

Pencahayaan alami rumah penderita ISPA pada balita di Desa Gandatapa untuk ruang kamar tidur yang memenuhi syarat kesehatan sebanyak 7 rumah $(14,29 \%)$, sedangkan untuk ruang keluarga yang memenuhi syarat sebanyak 19 rumah $(38,78 \%)$

Kondisi lantai rumah penderita ISPA di Desa Gandatapa untuk ruang kamar tidur dan ruang keluarga yang kedap air sebanyak 4 rumah $(8,16 \%)$.

Peneliti menyarankan agar pihak puskesmas menambah frekuensi penyuluhan kesehatan lingkungan kepada penderita ISPA dan rutin melakukan kunjungan rumah penderita ISPA untuk mengetahui kondisi rumah serta kebiasaan penghuni rumah.

\section{DaftarPustaka}

Azrul Anwar. 1986. Pengantar Ilmu Kesehatan Lingkungan. Jakarta: Mutiara Sumber Widya.

Budiman Chandra. 2007. Pengantar Kesehatan Lingkungan. Jakarta: Buku Kedokteran EGC.

Depkes RI. 1996. Pedoman Program Pemberantasan Penyakit Infeksi Saluran Pernafasan Akut untuk Penanggulangan Pnemonia Pada Balita Dlam Pelita IV. Jakarta: Dirjen PPM\&PLP.

Depkes RI. 1999. Keputusan Menteri Kesehatan No. 829/Menkes/SK/1999. Tentang

Persyaratan Kesehatan Perumahan. Jakarta: Depkes RI.
2002 a. Pedoman Pemberantasan Penyakit ISPA Pada Balita. Jakarta: Depkes RI.

2002 b. Direktorat Jenderal PPM\&PI. Jakarta: Depkes RI.

Depkes RI. 2011. Peraturan Menteri Kesehatan Republik Indonesia Nomor 1077/Menkes/Per/V/2011. Tentang Pedoman Penyehatan Udara Dalam Ruang Rumah. Jakarta: Depkes RI.

Djasio Sanropie. dkk. 1989. Pengawasan Kesehatan Lingkungan Pemukiman Untuk Institusi Pendidikan Tenaga Sanitasi Kesehatan Lingkungan, Jakarta: Purdiknakes Depkes RI.

Drs. Lud Waluyo, M.Kes. 2007. Mikrobiologi Umum. Malang: UMM Press.

https://www.scribd.com/document/350387316/jur nal-imunitas diakses pada hari Senin tanggal 28 Mei 2018 Pukul 14.41 WIB.

Jurnal Ilmiah Ilmu-Ilmu Kesehatan. Vol. XIV No.3/Desember 2016. Pengaruh Asap Rokok Terhadap Frekuensi Terjadinya Penyakit ISPA Pada Balita Di Puskesmas Kedung Banteng Banyumas.

Jurnal Kesehatan Lingkungan Indonesia. Vol.11 No.2/Oktober 2012. Hubungan FaktorFaktor Lingkungan Fisik Rumah Dengan Kejadian Pneumonia Pada Balita Di Wilayah Kerja Puskesmas Jatibarang Kabupaten Brebes.

Jurnal Kesehatan Masyarakat (e-Journal). Volume 2. Nomor 1. Januari 2014. Hubungan Antara Kondisi Lingkungan Fisik Rumah Dengan Kejadian Pneumonia Pada Balita Di Wilayah Kerja Puskesmas Pati I Kabupaten Pati.

Profil Kesehatan Kabupaten Banyumas. 2016. Dinas Kesehatan Kabupaten Banyumas. Propinsi Jawa Tengah.

Profil Kesehatan Puskesmas II Sumbang Tahun 2017.

Tatag Fajar Subekhi. 2010. Tinjauan Epidemiologi Penyakit Infeksi Saluran Pernafasan Akut (ISPA) Di Desa Sambeng Wetan Kecamatan Kembaran Kabupaten Banyumas Tahun 2010. Purwokerto: Politeknik Kesehatan Kemenkes Semarang Jurusan Kesehatan Lingkungan Purwokerto. 
Tri Ariyati. 2010. Studi Keadaan Sanitasi Rumah Penderita Penyakit ISPA Pada Balita Di Desa Gembong Kecamatan Gembong Kabupaten Pati Tahun 2010. Purwokerto: Politeknik Kesehatan Kemenkes Semarang Jurusan Kesehatan Lingkungan Purwokerto.

Tri Cahyono. 2017. Penyehatan Udara. Yogyakarta: Penerbit ANDI (Anggota IKAPI).
Yuli Trisnawati dan Juwarni. 2012. Hubungan Perilaku Merokok Orang Tua Dengan Kejadian ISPA Pada Balita Di Wilayah Kerja Puskesmas Rembang Kabupaten Purbalingga 2012. Purwokerto: Akdemi Kebidanan YLPP Purwokerto. 